\title{
INCREASE IN MERCURY IN PACIFIC YELLOWFIN TUNA
}

\author{
Paul E. Drevnick, $* \dagger$ Carl H. Lamborg, $\ddagger$ and Martin J. Horgan $\S$ \\ †University of Michigan Biological Station and School of Natural Resources and Environment, University of Michigan, Ann Arbor, Michigan, USA \\ $\ddagger$ Department of Marine Chemistry \& Geochemistry, Woods Hole Oceanographic Institution, Woods Hole, Massachusetts, USA \\ $\S$ Oxford, Ohio, USA \\ (Submitted 20 October 2014; Returned for Revision 17 November 2014; Accepted 4 January 2015)
}

\begin{abstract}
Mercury is a toxic trace metal that can accumulate to levels that threaten human and environmental health. Models and empirical data suggest that humans are responsible for a great deal of the mercury actively cycling in the environment at present. Thus, one might predict that the concentration of mercury in fish should have increased dramatically since the Industrial Revolution. Evidence in support of this hypothesis has been hard to find, however, and some studies have suggested that analyses of fish show no change in mercury concentration. By compiling and re-analyzing published reports on yellowfin tuna (Thunnus albacares) caught near Hawaii (USA) over the past half century, the authors found that the concentration of mercury in these fish currently is increasing at a rate of at least 3.8\% per year. This rate of increase is consistent with a model of anthropogenic forcing on the mercury cycle in the North Pacific Ocean and suggests that fish mercury concentrations are keeping pace with current loading increases to the ocean. Future increases in mercury in yellowfin tuna and other fishes can be avoided by reductions in atmospheric mercury emissions from point sources. Environ Toxicol Chem 2015;34:931-934. (C) 2015 SETAC
\end{abstract}

Keywords: Mercury Methylmercury Bioaccumulation

\section{INTRODUCTION}

Mercury is a potent toxin that can accumulate to high concentrations in fish, posing a health risk to humans who eat fish. Methylmercury, the predominant form of mercury in fish, is formed from mercuric ions $(\mathrm{Hg}[\mathrm{II}])$ by microbes and perhaps abiotically in waters and sediments, then enters the base of the food web and increases in concentration with each successive trophic level. Consumption of mercury-contaminated fish from gross pollution events-for example, in Minamata, Japan [1], where fish with concentrations as high as 36 ppm could "easily be captured by hand"- -has resulted in severe neurological damage in humans, most acutely in children exposed prenatally via maternal fish consumption. In waters not directly affected by local pollution, mercury concentrations in fish are typically less than $1 \mathrm{ppm}$. Even at this lower level, however, prenatal exposure is associated with developmental deficits [2]. Trasande et al. [3] found that annually in the United States, approximately 300000 to 600000 children are born with mercury concentrations in cord blood that exceed $5.8 \mu \mathrm{g} / \mathrm{L}$, a value associated with significant loss of IQ (intelligence quotient), the economic consequence of which is estimated to be $\$ 8.7$ billion annually in lost income.

Humans are exposed to methylmercury primarily by consumption of ocean fish [4]; and although models [5] and empirical data [6] suggest an increase in mercury content of the global ocean since preindustrial times, a corresponding increase in methylmercury has not been shown for ocean fish. Local pollution of nearshore environments occurs where there are point-source water discharges, but the principal source of mercury in the open ocean is atmospheric deposition [7].

All Supplemental Data may be found in the online version of this article.

* Address correspondence to drevnick@umich.edu.

Published online 1 February 2015 in Wiley Online Library

(wileyonlinelibrary.com).

DOI: $10.1002 /$ etc. 2883
Atmospheric mercury is now dominated by human contributions (primarily from fossil fuel combustion and artisanal gold mining), and present-day rates of mercury deposition are 3 times to 5 times greater than natural (pre-anthropogenic) rates [8]. Mercury pollution was thought to result in only a negligible increase in mercury concentration in open ocean waters [9], but a recent synthesis of data from water column profiles of total mercury points to a 2.6-times increase (since the 1500s) in waters shallower than $1000 \mathrm{~m}$, globally [6].

In the present study, we show a temporal increase in mercury concentration in a commercially important species, the yellowfin tuna (Thunnus albacares). Mercury data for Pacific yellowfin tuna from waters near Hawaii (USA) present a unique record because the same population and location were sampled 3 different times over $37 \mathrm{yr}$, muscle tissue samples were analyzed for mercury, and data were reported in peerreviewed literature. A network of fish aggregation devices in Hawaii have documented the high site fidelity of yellowfin tuna [10]. The following is a report of our compilation, reanalysis, and interpretation of the mercury data.

\section{METHODS}

We compiled published reports on mercury in yellowfin tuna caught from waters of the North Pacific Ocean near Hawaii during 1971 [11,12], 1998 [13], and 2008 [14]. From each specimen, muscle tissue was subsampled and measured for total mercury. Data are comparable across studies because of strict adherence to quality assurance/quality control (QA/QC) that ensured accuracy of data. Muscle tissue samples from 1971 [11,12] and 1998 [13] were acid digested and analyzed by cold-vapor atomic absorption spectrophotometry. Rivers et al. [11] reported that the mean recovery of spiked samples was $101 \%$ and that the result for each sample was validated by separate analysis of methylmercury, indeed confirming that nearly all of total mercury is methylmercury [15]. Thieleke $[12,16]$ had each sample analyzed by 2 independent 
laboratories, with excellent agreement between laboratories; the maximum deviation among samples was 6\%. Kraepiel et al. [13] reported detailed QA/QC procedures, including sample handling and use of duplicates (mean relative percent difference of $4.7 \%$ ), spikes (mean recovery of $96.7 \%$ ), and a reference sample (mean concentration of $0.128 \mathrm{ppm}$ with standard deviation of $0.0098 \mathrm{ppm}$ on 6 samples) for analyses. Muscle tissue samples from 2008 [14] were analyzed by thermal decomposition, amalgamation, and atomic absorption spectrophotometry. Choy et al. [14,17] also reported detailed QA/QC procedures, including analysis of duplicates (data accepted only if relative percent difference between duplicates was $<5 \%$ ) and certified reference materials (mean recoveries of DORM-3 and highpurity standard trace metal fish were $100.3 \%$ and $96.1 \%$, respectively).

To compare mercury concentrations among the 3 data sets (1971, 1998, and 2008), we used the analysis of covariance (ANCOVA) model, with body size as the covariate (Supplemental Data, Table S1). The ANCOVA model is the standard parametric test for comparing a characteristic of groups of subjects while controlling for the effect of another variable on that characteristic. Controlling for the effect of body size when assessing mercury concentration among groups of fish is thus a classic use of ANCOVA. Fish from $22 \mathrm{~kg}$ to $76 \mathrm{~kg}$ were included in the analysis, because this size range $( \pm 5 \mathrm{~kg})$ was common to all 3 data sets. It was necessary to remove the fish of less than $22 \mathrm{~kg}$ from the analysis, because these fish did not adhere to the assumption of linearity. Mercury concentrations in young tuna tend to be low but highly variable [18]. A diet shift occurs in young tuna when a critical body mass is developed that enables endothermic capability to allow access to prey in deeper, colder water [19]. At a certain size (depending on species), likely because of this ontogenetic diet shift, the relationship of mercury concentration versus size conforms to expectations (i.e., a linear relationship). Outliers, identified with Tukey box plots and confirmed by one-sided Grubbs' tests, were also removed from the data sets.

\section{RESULTS}

The ANCOVA indicated that slopes of the relationships between mercury concentration and fish size were not statistically different among the 3 time periods $\left(F_{2,223}=1.17\right.$, $p=0.31$; Figure 1), but mercury concentrations were higher in 2008 than in either 1971 or $1998\left(F_{2,225}=11.6, p<0.0001\right.$; Tukey's honest significant difference test; Figure 1). Accordingly, the average mercury concentration (least square mean \pm standard error) was considerably higher in 2008 $(0.336 \pm 0.023 \mathrm{ppm})$ than in $1971(0.229 \pm 0.008 \mathrm{ppm})$, or $1998(0.218 \pm 0.008 \mathrm{ppm})$. Sample size (for 1971, 1998, and $2008, n=111, n=104$, and $n=14$, respectively) is incorporated in the ANCOVA; and with the significant result, it can be ruled out-with $95 \%$ probability - that the effect of sample year was a result of chance. The 14 data points from 2008 are elevated relative to the 2 other data sets. Note that we conducted statistical diagnostics and found 5 points among the 3 data sets with potentially high leverage or high influence. We performed the ANCOVA without these points and found no change in the qualitative results of the ANCOVA (no difference in slopes, significant difference in intercepts).

\section{DISCUSSION}

Our analysis, at least for the early part of the record, is in agreement with that of Kraepiel et al. [13], who found no change

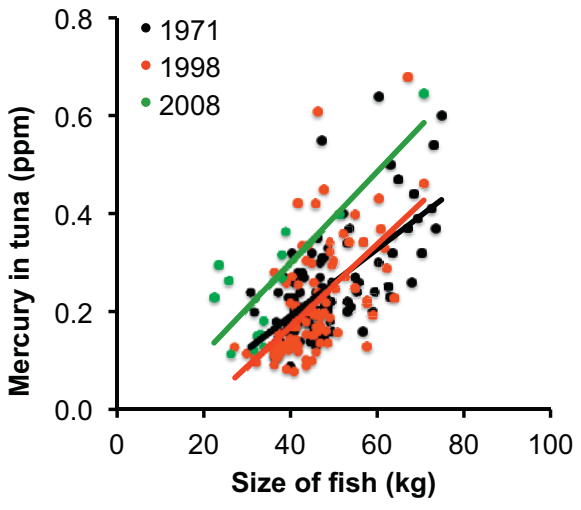

Figure 1. Linear regressions of fish size $(\mathrm{kg})$ versus $\mathrm{Hg}$ concentration (ppm) for 3 data sets for yellowfin tuna from North Pacific Ocean waters near Hawaii, USA; 1971 data set [11,12] (black): $\mathrm{Hg}=-0.0799+0.0068 \times$ mass, $n=111, r^{2}=0.413, p<0.0001 ; 1998$ data set [13] (red): $\mathrm{Hg}=$ $-0.1619+0.0083 \times$ mass $, \quad n=104, r^{2}=0.375, \quad p<0.0001 ; 2008$ data set [14] (green): $\mathrm{Hg}=-0.0718+0.0093 \times$ mass, $n=14, \quad r^{2}=0.656$, $p=0.0004$.

in tuna mercury between the same 1971 and 1998 data sets. This conclusion led Kraepiel et al. [13] to hypothesize that methylmercury forms from mercury naturally occurring in deep waters, sediments, or possibly hydrothermal vents and is therefore largely natural. Subsequently developed independent lines of evidence have suggested that vents are not strong enough sources of mercury to supply foodwebs [20], that fish do acquire methylated mercury from shallow depths in the ocean [21], and that seawater mercury concentrations are increasing oceanwide [6], including near Hawaii [22]. Thus, we should expect to see changes in the concentration of mercury in tuna now and in the foreseeable future.

Such changes are discernible in the recent part of the record, from 1998 to 2008, which shows an increase in mercury concentration in tuna at a rate of at least $3.8 \%$ per year, in agreement with recent and modeled changes in mercury cycling in the North Pacific Ocean (Figure 2). Sunderland et al. [22] found a significant rise in mercury concentrations in seawater at

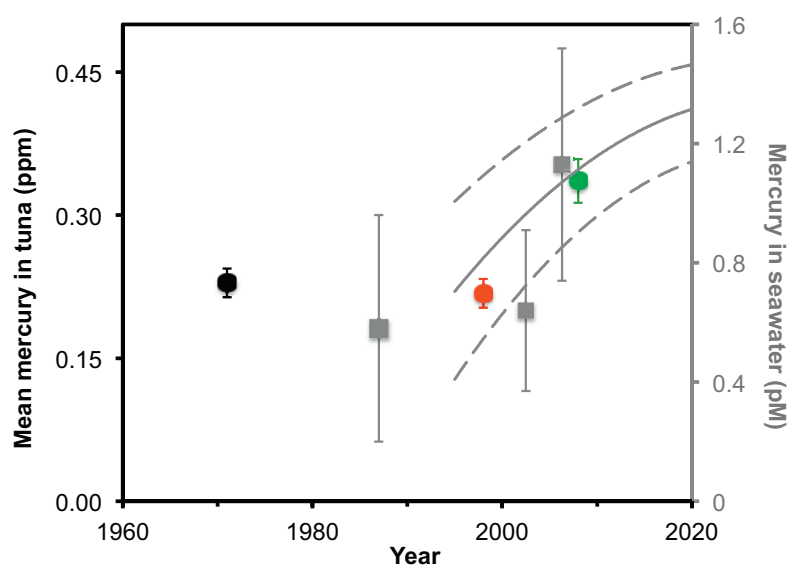

Figure 2. Least square mean ( \pm standard error) mercury concentration in yellowfin tuna from 1971 (black), 1998 (red), and 2008 (green) from waters near Hawaii, USA. Overlaid on the fish data are $\mathrm{Hg}$ concentrations in seawater; gray squares ( \pm standard deviation) represent point estimates from integrated 1000-m profiles in the eastern North Pacific Ocean, and the solid gray line represents modeled trends for intermediate waters (150$1000 \mathrm{~m}$ ) basin wide (dashed lines represent 95\% confidence interval). Seawater data and model output are from Sunderland et al. [22]. 
all depths (0-1000 m) from 2002 to 2006 . The largest increases, modeled at 3\% per year between 1995 and 2006, are occurring in intermediate waters $(150-1000 \mathrm{~m})$, which in addition to receiving mercury from atmospheric deposition to surface waters above $(0-150 \mathrm{~m})$ also receive inputs associated with lateral flow of mercury-enriched waters from the coast of the Northwest Pacific Ocean [22,23]. Yellowfin tuna near Hawaii spend most of their time in or immediately below surface waters [24]. The agreement between the data and modeling by Sunderland et al. [22] and the updated tuna record compiled and re-analyzed in the present study provides support for the alternative hypothesis that mercury and methylmercury concentrations in the ocean are increasing as a result of human activity and that anthropogenic methylmercury accumulates in commercially important fish.

A criticism of the Kraepiel et al. [13] study, that effects of fishing on oceanic food webs may have affected methylmercury accumulation in tuna [25], also applies to the present study. Data for age, growth, and trophic level are not available for the individual fish in our synthesis. In the Pacific Ocean, the largest tunas have become more rare, but no detectable change in trophic level has occurred in any population [26]. Growth statistics of yellowfin tuna appear unchanged over the past half century [27], but the data are not ideal for determining temporal trends. One could expect an increase in growth rate, as a densitydependent response to overexploitation of the population [28]. With increased growth, there would be growth dilution of mercury [29]. To summarize, no data suggest that Pacific yellowfin tuna have different growth rates or trophic level for the study period, but if either of those 2 factors changed, it would likely be in a direction that would tend to lower the concentration of mercury in tuna, masking the effect of increased mercury loading to the system.

Because fish mercury concentrations appear to be increasing in step with modeled loadings, these data indicate that mercury concentrations in open ocean fish are responsive to anthropogenic mercury releases. Lamborg et al. [6] suggested that if atmospheric mercury emissions continue to increase, the deep water sink will become overwhelmed in the coming decades. Therefore, the rate of increase in mercury in surface waters $(0$ $1000 \mathrm{~m}$ ) should be expected to be greater than the rate of increase in emissions. Mercury contamination of ocean fish is a serious global health issue, now being addressed by the United Nations Environment Programme's Minamata Convention on Mercury. Current goals of the convention-which aim to reduce atmospheric mercury emissions from point sources-would result in avoided increases in rates of atmospheric mercury deposition [30]. Even if current deposition rates are maintained, however, North Pacific Ocean intermediate waters are expected to double in mercury concentration by 2050 [22]. Thus, more stringent reductions in emissions are necessary.

\section{SUPPLEMENTAL DATA}

\section{Table S1. (74 KB PDF).}

Acknowledgment-P.E. Drevnick was supported by the University of Michigan and the Fonds de recherche du Québec-Nature et technologies. C.H. Lamborg was supported by the National Science Foundation (NSF OCE1129339, 1232760) and the Woods Hole Oceanographic Institution. B. Monson, E. Swain, and anonymous reviewers provided constructive comments on earlier drafts of the manuscript. The authors declare no competing financial interests or any other conflicts of interest. The supplemental data reported were previously published [11-14] but can also be found in Supplemental Data Table S1.

\section{REFERENCES}

1. Harada M. 1995. Minamata disease: Methylmercury poisoning in Japan caused by environmental pollution. Crit Rev Toxicol 25:1-24.

2. McKelvey W, Oken E. 2012. Mercury and public health: An assessment of human exposure. In Banks MS, ed, Mercury in the Environment: Pattern and Process. University of California Press, Oakland, CA, USA, pp 267-287.

3. Trasande L, Landrigan PJ, Schechter C. 2005. Public health and economic consequences of methyl mercury toxicity to the developing brain. Environ Health Perspect 113:590-596.

4. Sunderland EM. 2007. Mercury exposure from domestic and imported estuarine and marine fish in the U.S. seafood market. Environ Health Perspect 115:235-242.

5. Black FJ, Conaway CH, Flegal AR. 2012. Mercury in the marine environment. In Banks MS, ed, Mercury in the Environment, University of California Press, Oakland, CA, USA, pp 167-219.

6. Lamborg $\mathrm{CH}$, Hammerschmidt CR, Bowman KL, Swarr GJ, Munson KM, Ohnemus DC, Lam PJ, Heimbürger L-E, Rijkenberg MJA, Saito MA. 2014. A global ocean inventory of anthropogenic mercury based on water column measurements. Nature 512:65-68.

7. Mason RP, Fitzgerald WF, Morel FMM. 1994. The biogeochemical cycling of elemental mercury: Anthropogenic influences. Geochim Cosmochim Acta 58:3191-3198.

8. Engstrom DR, Fitzgerald WF, Cooke CA, Lamborg CH, Drevnick PE Swain EB, Balogh SJ, Balcom PH. 2014. Atmospheric Hg emissions from preindustrial gold and silver extraction in the Americas: A reevaluation from lake sediment archives. Environ Sci Technol 48:6533-6543.

9. Hammond AL. 1971. Mercury in the environment: Natural and human factors. Science 171:788-789.

10. Itano DG, Holland KN. 2000. Movement and vulnerability of bigeye (Thunnus obesus) and yellowfin tuna (Thunnus albacares) in relation to FADs and natural aggregation points. Aquat Living Resour 13: 213-223.

11. Rivers JB, Pearson JE, Shultz CD. 1972. Total and organic mercury in marine fish. Bull Environ Contam Toxicol 8:257-266.

12. Thieleke JR. 1973. Mercury levels in five species of commercially important pelagic fish taken from the Pacific Ocean near Hawaii. PhD Dissertation. University of Wisconsin-Madison, Madison, WI, USA.

13. Kraepiel AML, Keller K, Chin HB, Malcolm EG, Morel FMM. 2003. Sources and variations of mercury in tuna. Environ Sci Technol 37:5551-5558

14. Choy CA, Popp BN, Kaneko JJ, Drazen JC. 2009. The influence of depth on mercury levels in pelagic fishes and their prey. Proc Natl Acad Sci U S A 106:13865-13869.

15. Bloom NS. 1992. On the chemical form of mercury in edible fish and marine invertebrate tissue. Can J Fish Aquat Sci 49:1010-1017.

16. Boush GM, Thieleke JR. 1983. Total mercury content in yellowfin and bigeye tuna. Bull Environ Contam Toxicol 30:291-297.

17. Choy CA. 2013. Pelagic food web connectivity in the north Pacific subtropical gyre: A combined perspective from multiple biochemical tracers and diet. PhD Dissertation, University of Hawaii at Manoa, Honolulu, HI, USA

18. Cumont G, Viallex G, Lelièvre H, Bobenrieth P. 1975. Mercury contamination in sea fish. Translation Series No. 3373. Fisheries and Marine Service Canada, Halifax, NS.

19. Graham BS, Grubbs D, Holland K, Popp BN. 2006. A rapid ontogenetic shift in the diet of juvenile yellowfin tuna from Hawaii. Mar Biol 150:647-658.

20. Lamborg CH, Von Damm KL, Fitzgerald WF, Hammerschmidt CR, Zierenberg R. 2006. Mercury and monomethylmercury in fluids from Sea Cliff submarine hydrothermal field, Gorda Ridge. Geophys Res Lett 33:L17606.

21. Blum JD, Popp BN, Drazen JC, Choy CA, Johnson MW. 2013. Methylmercury production below the mixed layer in the North Pacific Ocean. Nat Geosci 6:879-884.

22. Sunderland EM, Krabbenhoft DP, Moreau JW, Strode SA, Landing WM. 2009. Mercury sources, distribution, and bioavailability in the North Pacific Ocean: Insights from data and models. Glob Biogeochem Cycles 23:GB2010, DOI:10.1029/2008GB003425

23. Hammerschmidt CR, Bowman KL. 2012. Vertical methylmercury distribution in the subtropical North Pacific Ocean. Mar Chem 132-133 $77-82$.

24. Brill RW, Block BA, Boggs CH, Bigelow KA, Freund EV, Marcinek DJ. 1999. Horizontal movements and depth distribution of large adult yellowfin tuna (Thunnus albacares) near the Hawaiian Islands, 
recorded using ultrasonic telemetry: Implications for the physiological ecology of pelagic fishes. Mar Biol 133:395-408.

25. Renner R. 2004. Where is the mercury? Environ Sci Technol 38:12A.

26. Sibert J, Hampton J, Kleiber P, Maunder M. 2006. Biomass, size, and trophic status of top predators in the Pacific Ocean. Science 314:1773-1776.

27. Zhu G, Xu L, Dai X, Liu W. 2011. Growth and mortality rates of yellowfin tuna, Thunnus albacares (Perciformes: Scombridae), in the eastern and central Pacific Ocean. Zoologia 28:199-206.
28. Polacheck T, Eveson JP, Laslett GF. 2004. Increase in growth rates of southern bluefin tuna (Thunnus maccoyii) over four decades: 1960 to 2000. Can J Fish. Aquat Sci 61:307-322.

29. Newman MC, Unger MA. 2003. Fundamentals of Ecotoxicology, 2nd ed. CRC Press, Boca Raton, FL, USA.

30. Selin NE. 2014. Global change and mercury cycling: Challenges for implementing a global mercury treaty. Environ Toxicol Chem 33: $1202-1210$. 